Article

\title{
Long-term Analysis of the Effects of Production Management in Coal Mining in Poland
}

\author{
Izabela Jonek-Kowalska
}

Faculty of Organization and Management, The Silesian University of Technology, 41-800 Zabrze, Poland; izabela.jonek-kowalska@polsl.pl; Tel.: +48-32-2777308

Received: 11 July 2019; Accepted: 8 August 2019; Published: 15 August 2019

\begin{abstract}
The primary aim of this article is to examine financial efficiency and work productivity, as well as their determinants, in selected Polish coal mines in 1998-2015. To achieve this goal, after introducing a justification for the choice of subject and the literature studies, the research methodology is presented, and research results are subsequently described and analyzed. Next, based on the main conclusions, model regularities and policy implications regarding efficiency and productivity improvement in Polish coal mining enterprises are established. The research for this study was conducted in five Polish coal mines, which were chosen on the basis of criteria aimed at ensuring the results' comparability and the stability of organizational and mining conditions in the analyzed research period.
\end{abstract}

Keywords: production management; coal mining in Poland; economic parameters in production processes; labor productivity; financial efficiency

\section{Introduction}

Coal mining is a traditional industry that is currently perceived as being in decline, especially in Europe, in conjunction with increasing decarbonisation and promotion of renewable energy sources $[1,2]$. The image of the coal mining industry is also worsened by its destructive influence on the environment and mining damages that disturb the life of local and regional communities [3,4]. Nevertheless, it should not be forgotten that the coal mining industry remains a significant and large employer, and that coal is still one of the main energy resources, even in Europe. Additionally, the changes in energy balances have occurred slowly; therefore, it should be assumed that societies will use coal as an energy carrier from a long-term perspective for a few decades to come [5-8].

The unfavorable economic situation is exacerbated by a long-lasting and deep decrease in coal prices in the international market. As a result, European mining enterprises have found themselves in a very difficult position, in which declining demand is accompanied with the price drop [9]. Unfortunately, the worsening financial profits resulted in the loss of investor confidence, which confirmed the falling stock prices of four European coal mining enterprises listed on Warsaw Stock Exchange from Poland (LW Bogdanka, Jastrzębska Spółka Węglowa-JSW), Czech Republic (New World Resources), and Ukraine (Coal Energy) [10,11].

In Poland, the situation of the coal mining industry is also complicated by a permanent loss of the competitiveness of Polish coal [12]. The unit cost of production has been high and has increased over time, which has discouraged national energy and heat producers from purchasing Polish steam coal, and as a result domestic demand is satisfied by coal importers, such as Russia and Kazakhstan, for which the dominant share of coal in the Polish energy balance is not only a waste of indigenous resources but also a threat for Poland's energy safety $[13,14]$. Reducing costs is a highly challenging task due to objective reasons, such as a high share of fixed costs and the deepening of excavation, 
and subjective reasons, such as social protests supported by numerous influential trade unions, as well as the threat of the pauperization of Upper Silesia [15-18].

In spite of all of the above arguments-notably factual and accurate-Polish coal mining requires decisive and consequential actions in the area of efficiency and productivity improvement $[19,20]$ because otherwise the inability to reduce costs in this specific industry could result in sector liquidation [21]. Therefore, in this article, the long-term analysis of economic parameters is presented, and their results are used to formulate some frameworks for corporate management in the selected existing Polish coal mines.

\section{Materials and Method}

\subsection{Theoretical Background}

The most important economic parameters for each enterprise operating in a free-market economy are labor productivity and financial efficiency. The first of these indices should be oriented toward the maximisation of production volume while maintaining the workers' safety and health in current internal and external conditions. Such an economically rational approach enables the maximum spreading of fixed costs and optimises the unit costs of production. It also allows for the appropriate and optimal usage of the infrastructure, machinery and equipment, work force and the enterprise's other resources. From this point of view, striving for the optimal volume of production seems to be especially important in industries that are characterised by a high level of fixed costs, which includes coal mining.

Labor productivity optimization is strictly connected with the second economic parameter, financial efficiency, which is understood and measured in relative terms as a financial result linked to expenditures, assets, or capital [22]. To exist in an enterprise's long-term perspective, efficiency must be positive, and consequently, revenue must be higher than costs. In increasing market competitiveness and economies' globalization, an enterprise's influence on revenue (prices and demand) is very limited, and as a result, the only way of improving financial efficiency is cost optimization. Achieving this goal allows the enterprise to gain and maintain a price-competitive advantage, which is especially important in the case of industries in which, due to product homogeneity, the other types of competitiveness do not matter significantly. Coal mining is undoubtedly such an industry with limited influence on its quality, distribution, or marketing strategy.

Polish coal mining has fought to reach positive financial efficiency and to gain stable price competitiveness for many years, since the recovery of economic freedom in 1989. Until recently, the core cause of the failure of these efforts has been high and decreasing costs of production with a huge share of fixed costs, including more than fifty percent of remuneration. Currently, the financial efficiency is additionally worsened by decreasing revenues resulting from both falling prices and declining demand. Thus, the need for effective and radical cost reduction has risen dramatically.

In the literature, the issue of the efficiency and cost of coal mining is considered relatively rarely because this topic does not fit in the contemporary discussion about the finances of industrial organizations. Currently, efficiency and cost problems in manufacturing enterprises are addressed in three main research trends. The first trend concerns implementing new technologies and innovation into production processes that are aimed at cost reduction and efficiency optimization [23,24]. The second trend concentrates on the role of products' and processes' quality [25-27] in cost management, and the third trend associates environmental protectio issues, such as carbon dioxide emissions and renewable resources production, with the problem of cost and efficiency optimization [28-31]. Each of these research areas focuses on a process approach $[32,33]$ and analyze costs and efficiency related to product lifecycle management [34,35].

There are several reasons for the lack of major interest in these fundamental issues of financial efficiency and labor productivity in the coal mining industry. Primarily, most coal mining enterprises in the world operate as multinational corporations and are equipped in terms of knowledge, skills, experiences, and instruments-enabled effective financial management, and are adjusted to contemporary economies' standards. The level of management advancement in these organizations indicates that 
they are interested in more complex issues that are analyzed in the three research areas described above. Furthermore, in Europe, due to efficiency and competitiveness problems, the majority of coal mining enterprises in the whole industry were liquidated. As a result, the problem of efficiency in the coal mining sector has become a regional one and now concerns mainly Central-Eastern European countries such as Poland, Czech Republic, Romania, and Ukraine.

In Polish literature, efficiency is considered primarily in the context of the analysis and reduction of costs, and there have been no studies of complex and long-term solutions for financial efficiency and labor productivity in Polish coal mines [36]. However, research in the area of costs was undertaken in the 1970s at the Main Mining Institute after the economic transition that framed the coal mining restructure [37-41]. Costs were examined in terms of time, and their structure was analyzed, usually at the level of the whole industry or a specific coal mining enterprise. Moreover, much attention was paid to cost planning and controlling, [42-46] which was quite complicated and lacked detailed cause and effect cost analyses. According to the presented review, the necessity of continuing and deepening the research about cost management is the result mainly of practical concerns, such as worsening price competitiveness in Polish coal mining and the risk of losing energy safety in Poland, but there is also a need to supplement the quite modest theory concerning financial efficiency and labor productivity in mining enterprises. Therefore, the main aim of this article is to examine financial efficiency and work productivity, as well as their determinants, in selected Polish coal mines in 1998-2015. To achieve this goal, in the next part of the article the research methodology is presented, then research results are described and analyzed. Next, based on the main conclusions, model regularities and policy implications regarding efficiency and productivity improvement in Polish coal mining enterprises are established.

\subsection{Methods and Data}

The research was conducted in five Polish coal mines ( $\mathrm{CM}-\mathrm{a}$ coal mine). These coal mines were chosen on the basis of the following criteria aimed at ensuring the results' comparability and the stability of organizational conditions in the analyzed research period:

- Coal mining by underground methods;

- Steam coal production;

- A lack of organizational changes such as merging or separating coal mines;

- Good financial results and the sufficiency of coal reserves, guaranteeing long-term perspective of excavation.

The period of the study covered 18 years (from 1998 to 2015) and allowed the establishment of a long-term analysis of labor productivity and financial efficiency in a quite stable geological, mining, and organizational environment. The above assumptions made it possible to propose answers to the following research questions (RQ):

RQ1: How does labor productivity change over time, and what are its main determinants?

RQ2: How do costs and financial efficiency change in long-time perspectives?

RQ3: Are the changes in unit costs economically rational? What factors influence changes in the production costs?

These assumptions also help verify the following research hypotheses (RH):

RH1: Labor productivity is characterized by high fluctuations over time in a sole coal mine (A) and in the whole sample examined (B)

RH2: Labor productivity changes over time, mostly under the influence of changes in production volume

RH3: The total costs of production are not correlated with employment level (A) and the volume of production (B)

RH4: Linear regression functions illustrate the dependence of total costs on production volume in examined coal mines and indicate the economic irrationality of stated correlations. 
RH5: The highest financial efficiency characterizes the coal mines with economically rational relations between production, employment. and total costs.

These research hypotheses were formulated on the basis of fundamental economic relations between production volume, total costs, and employment level. Generally, total production costs depend on production volume and should change in correlation with it, regardless of the share of fixed and variable costs. The linear regression function illustrates the division of costs into fixed and variable $[47,48]$ (and its goodness of fit to production data that confirms stability and the transparency of this split. Consequently, unit costs should decrease with an increase in production.

Labor productivity should guarantee the best possible spreading of fixed costs and, as a result, the best financial efficiency. In similar production conditions, it is stable over time, and on the basis of historical data the enterprise could establish its optimal level. In conditions of decreasing demand and the need to reduce production, the level of employment should be adapted to the current market situation and optimal labor productivity should be at least maintained at optimal levels in order for the enterprise to limit a drop in efficiency. Additionally, in industries with a high level of fixed costs, in such situations the increase of labor productivity is recommended because of low cost flexibility and to protect the financial results from declining dramatically. At this point, it is worth noting that a failure to comply with the above rules should not be justified by the specificity of the industry because these rules are immutable and absolute, and the consequences of omitting them are always the same and mean the bankruptcy of an enterprise.

In the research process, the following methods are used:

1. Indices of dynamics for measuring the level of changes:

$$
I_{d}=\frac{x_{i}}{x_{0}}
$$

where:

$x_{i}$-value in the examined period,

$x_{0}$-value in the based period.

Coefficients of variation for estimating the range of observed changes:

$$
C V=\frac{s(x)}{\bar{x}}
$$

where:

$\bar{x}$-arithmetic average,

$s(x)$-standard deviation.

2. Pearson linear correlation coefficients for checking the relation between examined economic parameters:

$$
r_{x y}=\frac{\operatorname{cov}(x, y)}{s(x) \cdot s(y)}
$$

where:

$\operatorname{cov}(x, y)$ - covariation of $x$ and $y$,

$s(x), s(y)$ - standard deviations of $x$ and $y$.

3. Coefficients of determination for assessing the range of influence:

$$
\varphi^{2}=r_{x y}^{2}
$$

where:

$r_{x y}$-Pearson linear correlation coefficients of $x$ and $y$.

4. Linear regression functions to describe the relations between total costs and the volume of production:

$$
y=a_{0}+a_{1} \cdot x_{1}+\varepsilon
$$


where:

$a_{i}$-regression coefficients,

$x_{1}$ - explanatory variable,

$\varepsilon$-error term.

The data for calculations were collected from examined coal mines and statistical sources from the Ministry of Economy.

\section{Results}

The average labor productivity in examined coal mines ranged from $743 \mathrm{Mg}$ per employee (CM4) to $908 \mathrm{Mg}$ per employee (CM5), and in this context was not highly varied (Table 1 and Figure 1). The lowest productivity was observed in 1998 at the beginning of the deep restructuring in Polish coal mining. After this period it increased, but it was still very diverse in time and between particular coal mines. In 2008 productivity decreased again, which was the result of reduced demand and decarbonization. In 2014, market demand was growing and simultaneously examined coal mines were restructuring employment, which resulted in a significant increase in productivity.

However, the differences between the maximum and minimum over time and between particular coal mines indicates a significant differentiation of labor productivity. In all coal mines, labor productivity visibly decreased in periods of economic downturns associated with the decline of coal prices. In two of five coal mines, changes in labor productivity could be explained by changes in the production level (CM2 and CM4). In the remaining three coal mines, changes in labor productivity were mainly determined by employment fluctuations (CM1, CM3, CM5) (Tables 2 and 3).

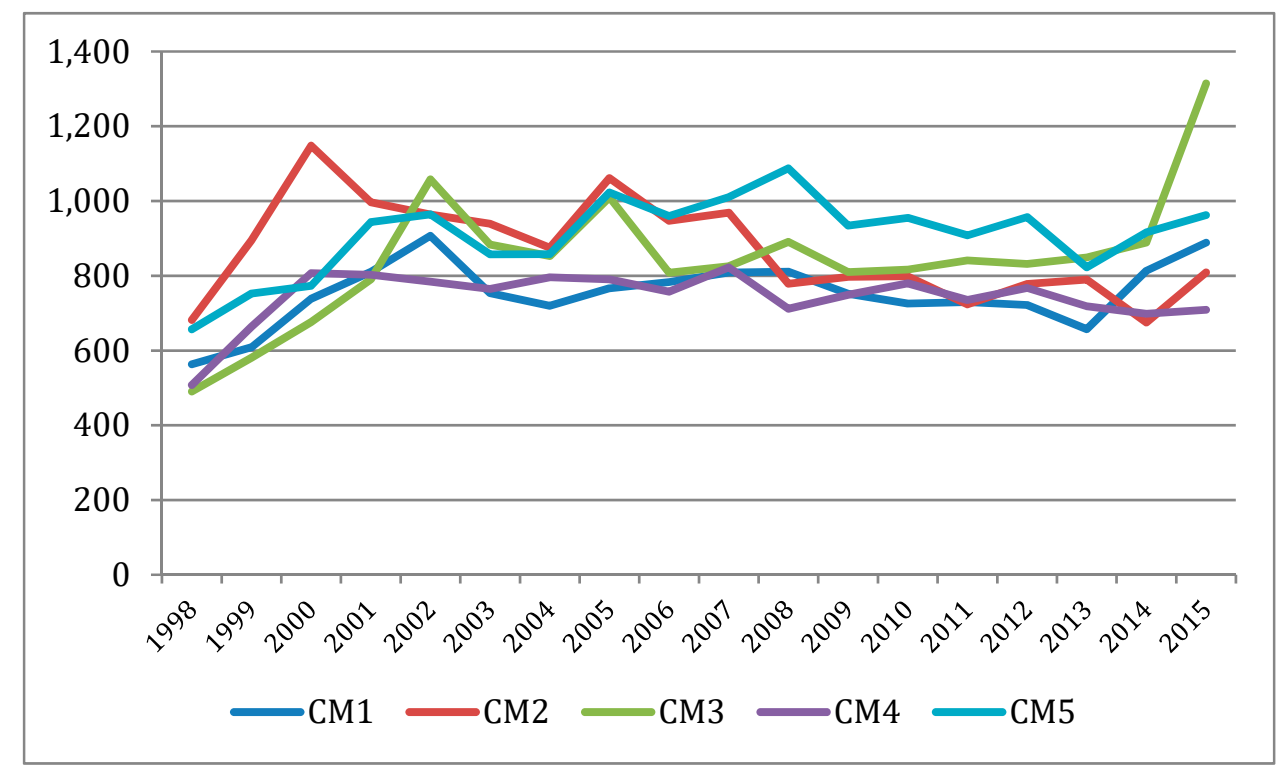

Figure 1. The labor productivity in examined coal mines (CM) in 1998-2015 (yearly in Mg per emoloyee). 
Table 1. Descriptive statistics for labor productivity in examined coal mines (in Mg per employee).

\begin{tabular}{ccccccc}
\hline $\begin{array}{c}\text { Coal Mine * } \\
\text { No. }\end{array}$ & $\begin{array}{c}\bar{x}- \\
\text { Arithmetic } \\
\text { Average }\end{array}$ & $\begin{array}{c}s(\boldsymbol{x})- \\
\text { Standard } \\
\text { Deviation }\end{array}$ & $\begin{array}{c}C V \text {-Coefficients } \\
\text { of Variation }\end{array}$ & Maximum & Minim & $\begin{array}{c}\text { Maximum- } \\
\text { Minimum }\end{array}$ \\
\hline CM1 & 753 & 83.76 & $11.12 \%$ & 907 & 563 & 344 \\
CM2 & 868 & 127.43 & $14.68 \%$ & 1148 & 675 & 473 \\
CM3 & 845 & 171.55 & $20.29 \%$ & 1315 & 490 & 824 \\
CM4 & 743 & 70.64 & $9.51 \%$ & 822 & 508 & 315 \\
CM5 & 908 & 102.54 & $11.29 \%$ & 1088 & 657 & 431 \\
\hline
\end{tabular}

Table 2. Pearson linear coefficients $\left(r_{x y}\right)$ between labor productivity and production volume, employment and total costs.

\begin{tabular}{cccccc}
\hline \multirow{2}{*}{ Specification } & \multicolumn{5}{c}{ Coal Mine (CM) } \\
\cline { 2 - 6 } & CM1 & CM2 & CM3 & CM4 & CM5 \\
\hline Production & -0.0348 & $0.7145^{*}$ & -0.1784 & $0.7471^{*}$ & 0.4454 \\
Employment & $-0.8308^{*}$ & -0.3272 & $-0.7586^{*}$ & 0.2891 & $-0.7835^{*}$ \\
Total costs & -0.2390 & $-0.6894^{*}$ & -0.3167 & 0.3693 & -0.0233 \\
\hline \multicolumn{7}{c}{${ }^{*}$ level of significance $p<0.05}$.
\end{tabular}

Table 3. Determination coefficients $\left(\varphi^{2}\right)$ between labor productivity and production volume, employment, and total costs.

\begin{tabular}{|c|c|c|c|c|c|}
\hline \multirow{2}{*}{ Specification } & \multicolumn{5}{|c|}{ Coal Mine (CM) } \\
\hline & CM1 & CM2 & СM3 & CM4 & CM5 \\
\hline Production & $0.12 \%$ & $51.05 \%$ * & $3.18 \%$ & $55.82 \%$ * & $19.84 \%$ \\
\hline Employment & $69.02 \%$ * & $10.71 \%$ & $57.55 \%$ * & $8.36 \%$ & $61.39 \%$ * \\
\hline Total costs & $5.71 \%$ & $47.53 \%$ * & $10.03 \%$ & $13.64 \%$ & $0.05 \%$ \\
\hline
\end{tabular}

According to the above results, two coal mines (CM 2 and $\mathrm{CM} 4)$ require stronger relations between labor productivity and employment. All of them should maintain labor productivity at a level comparable to the maximum, which enables financial efficiency optimization. Observed differences between max and min, and their connections with worsening market situations, suggest a lack of adaptation in employment to decreasing demand, in spite of the fact that examined coal mines have the best financial results in Polish coal mining.

With respect to the research hypotheses and the coefficients of variation (Table 1), the first hypothesis (H1) could not be confirmed because labor productivity was characterized by higher-than-average fluctuations over time in a sole coal mine (A) and in the whole examined sample (B). Nevertheless, the dispersion between max and min (especially in CM3) indicates the unsustainability of production possibilities and the occurrence of periods of unjustified reductions in labor productivity. The second research hypothesis (H2) stated that labor productivity changes over time, mostly under the influence of changes in production volume. This hypothesis could be confirmed only partly in the case of CM2 and CM4. In three remaining coal mines, labor productivity was strongly and rationally correlated with employment level.

In turn, economically rational and statistically significant correlations between total costs and production volume as well employment level existed only in $\mathrm{CM} 3$ and partially-with respect to employment-in CM2 (Tables 4 and 5). In the rest of the cases, the correlations were insignificant and sometimes additionally negative, which indicates that increases in total costs were accompanied with production and employment decreases. 
Table 4. Pearson linear coefficients $\left(r_{x y}\right)$ between total costs and production volume and employment.

\begin{tabular}{cccccc}
\hline \multirow{2}{*}{ Specification } & \multicolumn{5}{c}{ Coal Mine (CM) } \\
\cline { 2 - 6 } & CM1 & CM2 & CM3 & CM4 & CM5 \\
\hline Production & -0.3677 & -0.2647 & $0.8413 *$ & -0.0072 & -0.1035 \\
Employment & 0.0582 & $0.5303 *$ & $0.7772 *$ & -0.2898 & -0.0463 \\
\hline \multicolumn{7}{c}{ * level of significance $p<0.05}$.
\end{tabular}

Table 5. Determination coefficients $\left(\varphi^{2}\right)$ between total costs and production volume and employment.

\begin{tabular}{cccccc}
\hline \multirow{2}{*}{ Specification } & \multicolumn{5}{c}{ Coal Mine (CM) } \\
\cline { 2 - 6 } & CM1 & CM2 & CM3 & CM4 & CM5 \\
\hline Production & $13.52 \%$ & $7.01 \%$ & $70.78 \%$ * & $0.01 \%$ & $1.07 \%$ \\
Employment & $0.34 \%$ & $28.12 \%$ * & $60.40 \%$ * & $8.40 \%$ & $0.21 \%$ \\
\hline \multicolumn{7}{c}{ * level of significance $p<0.05}$.
\end{tabular}

The above tendencies were reflected in the constant increase of the unit cost, which raised from $22 \%$ (CM3) to 65\% (CM4) during the 18 years period of analysis of constant prices in 1998 (Figure 2 and Table 6).

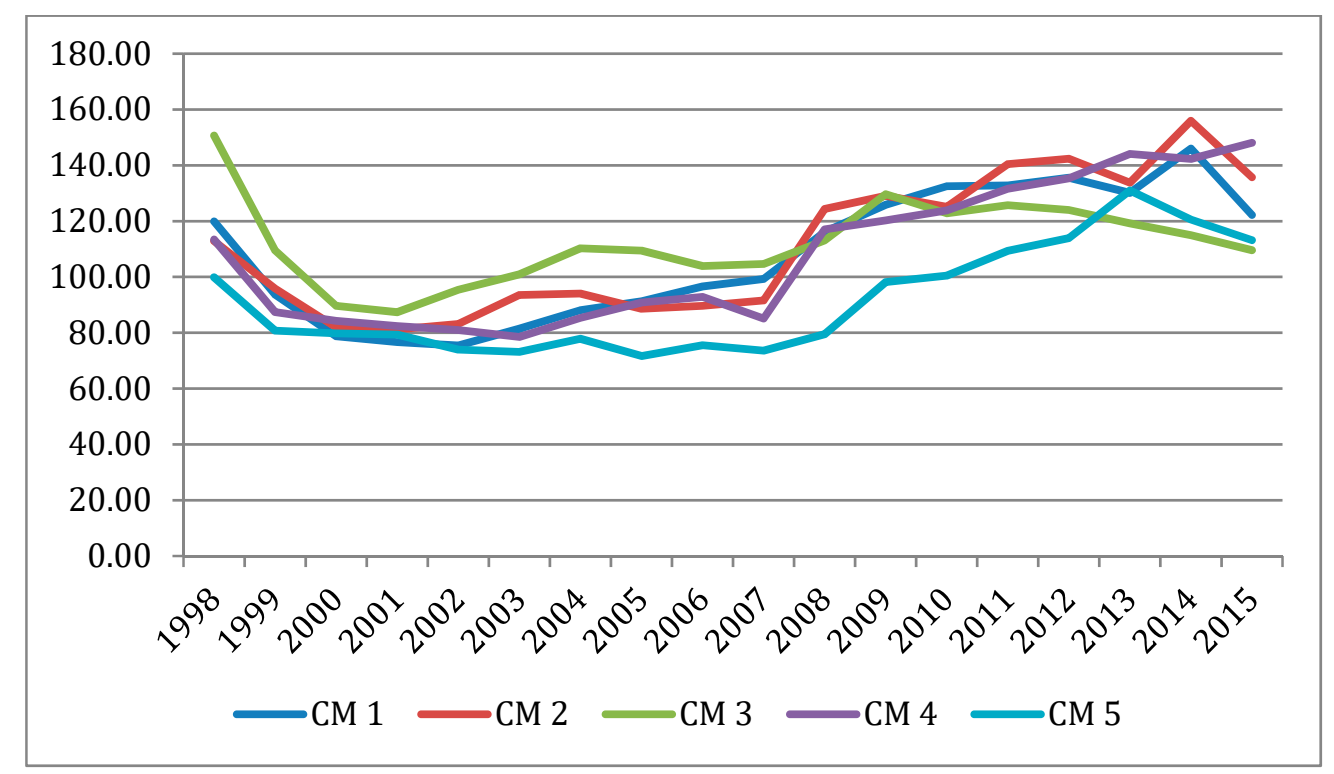

Figure 2. The unit costs in examined coal mines (CM) in constant prices of 1998 (in PLN per Mg). 
Table 6. Chain indices of dynamics in examined coal mines (CM) in 1998-2015.

\begin{tabular}{cccccccccc}
\hline \multirow{2}{*}{ Specification } & \multicolumn{7}{c}{ Year } \\
\cline { 2 - 10 } & $\mathbf{1 9 9 8}$ & $\mathbf{1 9 9 9}$ & $\mathbf{2 0 0 0}$ & $\mathbf{2 0 0 1}$ & $\mathbf{2 0 0 2}$ & $\mathbf{2 0 0 3}$ & $\mathbf{2 0 0 4}$ & $\mathbf{2 0 0 5}$ & $\mathbf{2 0 0 6}$ \\
\hline CM1 & 1.0000 & 1.0806 & 1.2141 & 1.0972 & 1.1188 & 0.8307 & 0.9548 & 1.0653 & 1.0220 \\
CM2 & 1.0000 & 1.3128 & 1.2834 & 0.8679 & 0.9673 & 0.9741 & 0.9322 & 1.2126 & 0.8923 \\
CM3 & 1.0000 & 1.1842 & 1.1640 & 1.1695 & 1.3381 & 0.8354 & 0.9651 & 1.1843 & 0.8002 \\
CM4 & 1.0000 & 1.3072 & 1.2159 & 0.9948 & 0.9767 & 0.9751 & 1.0410 & 0.9928 & 0.9589 \\
CM5 & 1.0000 & 1.1460 & 1.0272 & 1.2208 & 1.0218 & 0.8892 & 1.0005 & 1.1920 & 0.9385 \\
\hline \multirow{2}{*}{ Specification } & & & & & Year & & & & \\
\cline { 2 - 10 } & $\mathbf{2 0 0 7}$ & $\mathbf{2 0 0 8}$ & $\mathbf{2 0 0 9}$ & $\mathbf{2 0 1 0}$ & $\mathbf{2 0 1 1}$ & $\mathbf{2 0 1 2}$ & $\mathbf{2 0 1 3}$ & $\mathbf{2 0 1 4}$ & $\mathbf{2 0 1 5}$ \\
\hline CM1 & 1.0325 & 1.0027 & 0.9277 & 0.9650 & 1.0052 & 0.9893 & 0.9108 & 1.2374 & 1.0926 \\
CM2 & 1.0227 & 0.8036 & 1.0241 & 1.0020 & 0.9061 & 1.0750 & 1.0153 & 0.8546 & 1.1980 \\
CM3 & 1.0213 & 1.0790 & 0.9094 & 1.0079 & 1.0305 & 0.9886 & 1.0207 & 1.0473 & 1.4785 \\
CM4 & 1.0854 & 0.8653 & 1.0527 & 1.0408 & 0.9426 & 1.0447 & 0.9355 & 0.9724 & 1.0154 \\
CM5 & 1.0530 & 1.0760 & 0.8588 & 1.0225 & 0.9508 & 1.0542 & 0.8596 & 1.1132 & 1.0506 \\
\hline
\end{tabular}

The lack of rationality in changes of total and unit costs resulted in the lack of possibility for fit regarding linear regression functions. According to the data presented in Table 7, good and significant fit for the regression function-illustrating the dependency of the total costs from the production level-was possible only in coal mine no. 3 , in which the relations between employment and production from an economic point of view were the most coherent.

Table 7. Linear regression functions for examined coal mines (CM) (total costs dependency from production volume).

\begin{tabular}{cccccc}
\hline \multirow{2}{*}{ Specification } & \multicolumn{5}{c}{ Coal Mines } \\
\cline { 2 - 6 } & CM1 & CM2 & CM3 & CM4 & CM5 \\
\hline$R^{2}$ & 0.1352 & 0.0700 & 0.7078 & 0.00005 & 0.0107 \\
$R_{a d j}{ }^{2}$ & 0.1812 & 0.0119 & 0.6896 & - & - \\
$F$ & $F(1.16)=2.5019$ & $F(1.16)=1.2054$ & $F(1.16)=38.766$ & $F(1.16)=0.0008$ & $F(1.16)=0.1734$ \\
$p$ & $p<0.1333$ & $p<0,2885$ & $p<0.0001$ & $p<0.9774$ & $p<0.6826$ \\
$y$ & $y=-0.3677 x+$ & $y=-0.2647 x+$ & $y=0.8413 x-$ & $y=0.00071 x+$ & $y=-0.1035 x+$ \\
& 534376740 & 422624570 & 89430427 & 506854732 & 474856257 \\
\hline
\end{tabular}

According to the results, the third research hypothesis (H3), which stated that the total costs of production are not correlated with employment level (A) and the volume of production (B), could be confirmed. The results also supported the fourth research hypothesis (H4), which stated that linear regression functions illustrate the dependence of total costs on production volume in examined coal mines, and indicate the economic irrationality of stated correlations. The only exception in the sample is coal mine no. 3, for which the examined relations and the linear regression function were correct.

CM3 was characterized by the highest average financial efficiency and the lowest number of inefficiency periods. Its economic parameters were also economically rational, which confirms hypothesis $\mathrm{H} 5$, which stated that the highest financial efficiency characterizes the coal mines with economically rational relations between production, employment, and total costs. Nevertheless, besides this regularity, it is worth noting that financial efficiency fluctuations are very high in all examined coal mines (Table 8). They do have positive financial results, but the coefficient of variations and the dispersion between max and min were extremely large. It is a consequence of two simultaneously occurring circumstances: The constant unit cost increase and price fluctuations (the price in the examined period ranged from 32 USD per Mg to 147 USD per Mg). In such unstable economic conditions, conscientiousness about stabilizing labor productivity and stopping the growth of unit costs should be a priority in all examined coal mines, even if their financial results are satisfying. In this 
context, it should be not allowed to increase the wages during an economic recovery period, which frequently took place in previous years and led to an irreversible increase in unit costs.

Table 8. Descriptive statistics for financial efficiency in examined coal mines (CM) (in \%).

\begin{tabular}{ccccccc}
\hline $\begin{array}{c}\text { Coal Mine } \\
\text { No. }\end{array}$ & $\begin{array}{c}\bar{x} \text {-Arithmetic } \\
\text { Average }\end{array}$ & $\begin{array}{c}s(\boldsymbol{x}) \text {-Standard } \\
\text { Deviation }\end{array}$ & $\begin{array}{c}\boldsymbol{C V} \text {-Coefficients } \\
\text { of Variation }\end{array}$ & Maximum & Minimum & $\begin{array}{c}\text { Maximum } \\
\text {-Minimum }\end{array}$ \\
\hline CM1 & $22.64 \%$ & $31.85 \%$ & $140.67 \%$ & $120.30 \%$ & $-20.17 \%$ & $140.47 \%$ \\
CM2 & $19.10 \%$ & $29.97 \%$ & $156.94 \%$ & $105.71 \%$ & $-18.06 \%$ & $123.77 \%$ \\
CM3 & $27.54 \%$ & $34.93 \%$ & $126.83 \%$ & $147.72 \%$ & $-30.42 \%$ & $178.14 \%$ \\
CM4 & $11.46 \%$ & $29.82 \%$ & $260.10 \%$ & $97.76 \%$ & $-31.46 \%$ & $129.22 \%$ \\
CM5 & $24.92 \%$ & $42.71 \%$ & $171.37 \%$ & $175.84 \%$ & $-17.84 \%$ & $193.68 \%$ \\
\hline
\end{tabular}

\section{Discussion}

The long-term analysis of economic parameters in mining production was conducted in the selected coal mines, characterized by good financial situations and advantageous geological and mining conditions. The chosen units also stood out in terms of the long-term sufficiency of coal reserves. As a result, they could be qualified as coal mines with the largest chances of surviving in Polish coal mining in unfavorable development conditions. Nevertheless, the undertaken analysis revealed a number of economic anomalies that require systematic improvement.

Primarily, the coal mines should precisely identify market demand and then adapt their production levels to it. This step should be performed not only at the level of total production volume, but also by type of assortment. In the examined group of coal mines, the quality of excavated coal varied; some of them could supply coal mainly for the energy sector because of the low calorific value of the coal extracted, and some could sell it to the heating sector and to individual clients. In this respect, the efficiency calculation should be made in a particular coal mine and in relation to the entire grouping in which the mines operate. Currently, production levels are planned on the basis of previous periods and on the changeable market conditions, which should not be the only factors taken into account in planning.

The second, far more complicated problem is how to adapt employment and productivity to rationally planned production volume. Observed changes in labor productivity and relations between production and employment indicate the randomness of the obtained results. Meanwhile, the maintenance of optimal labor productivity is crucial for minimalizing the unit costs achieved due to better fixed cost spreading.

In present market conditions with declining demand, adapting employment to production volume is usually associated with radical employment restructuring, usually entailing a reduction of staff. Nevertheless, it should be emphasized that worsening efficiency in Polish coal mining is not only the result of decreasing demand but, above all, the lack of price competitiveness. So, the problem is not where to sell but how to sell cheaper and better quality coal. At a fifty percent share of remuneration in total costs, unit cost reduction without reduction of wages is impossible, but due to optimizing labor productivity and making the wages system more elastic, the negative consequences of employment restructuring could be significantly limited.

Currently, the wages system is not associated with labor productivity and financial efficiency, and in the mining literature and practice, wages are treated as $100 \%$ fixed costs, which is completely inconsistent with accounting and finance rules, according to which, the wages of production workers are $100 \%$ included in variable costs. This approach should be systematically changed through the introduction of motivation (the third fundamental management function) and by opening the possibility of at least partially adjusting wages according to changing market conditions, which does not entail only employment reduction.

Inflexibility of wages is caused by a high level of basic wages and the lack of elements dependent on performance or financial results. Such wages planning makes it impossible to survive and to adapt to market changes, especially in such a traditional, and rather declining, industry as hard coal mining. 
It is also worth noting that the research did not take into account an important variable, which is the cost of transportation affecting coal's final competitiveness because it is reported at the level of selling costs but significantly raises the sale price. Statistically, in recent years, the average distance of hard coal transport in domestic relations amounted to approximately $140 \mathrm{~km}$, and in the import relations, approximately $190 \mathrm{~km}$. At such distances, the railway transport rates are $0.5 \mathrm{USD} / \mathrm{GJ}$ for $140 \mathrm{~km}$, and $0.6 \mathrm{USD} / \mathrm{GJ}$ for $180 \mathrm{~km}$. They are one of the highest rates in the European Union. Only Estonia, Lithuania, Latvia, and Slovakia have more expensive railway transport. In countries such as Spain, Sweden, Slovenia, and Portugal, rail transport is the cheapest. It is also worth adding that the quality, including the speed, of rail transport in Poland is lower than the average in the European Union and is improving quite slowly. This is one of the main barriers to the development of rail transport in Poland, including a barrier limiting the import of hard coal to Poland.

The tasks mentioned above are a long-term one with deferred effects, but without their implementation, permanent improvement in financial efficiency achieved by rational costs reduction will fail even in the best Polish coal mines.

\section{Conclusions}

In this study, we attempted to answer the research questions stated in the methodology section of this article. According to the research results, labor productivity in examined coal mines is, on average, unstable over time with a large dispersion between maximum and minimum values. In two of five coal mines, this productivity was mainly determined by changes in production volume, and in the remaining three, it depended on employment level.

Total costs and unit costs systematically increased over time and in only one coal mine indicated an economically rational correlation with production volume and employment level that enabled the establishment of linear regression functions illustrating dependence of total costs on production volume and determining the allocation between fixed and variable costs. Increasing unit costs, combined with the high amplitude of coal price fluctuations, causes extremely large changes in financial efficiency over time, which intensify operational risk, even in the coal mines that are in good economic and mining conditions, such as the examined coal mines. At this point, it is worth noting that the coal mines with economically rational relations between total costs and production and employment level achieved the best average efficiency in the whole sample, which partially confirms a theoretical and practical possibility of coal mining's adjustment to general economic rules and their effectiveness.

As we have already mentioned, attempts to rationalize employment have been made in Polish mines for years. Nevertheless, their results are not satisfactory. Both the level of employment and the level of wages are inflexible and do not depend on the volume of production or the economic situation. In recent years, it has led to a deep collapse of hard coal mining and the liquidation of several mines. Nevertheless, if this problem is not successfully and permanently resolved, the remaining mines-even within the power engineering structures-will pose a threat both for themselves and energy enterprises.

Beside the economic suggestions, the research results allow the formulation of several management recommendations. Proper management in an enterprise is guaranteed by the implementation and constant improvement of four fundamental management functions: Planning, organizing, motivating, and controlling. In the examined cases-as in the entire Polish coal mining sector-effective planning and motivation is missing. Without the right application, a stable financial situation for coal mines will be highly difficult to achieve and maintain.

Funding: This research was founded by Silesian University of Technology, grant number No. 13/010/BK_19/0034. Conflicts of Interest: The authors declare no conflict of interest. 


\section{References}

1. Gawlik, L.; Majchrzak, H.; Mokrzycki, E.; Uliasz-Bocheńczyk, A. Perspektywy węgla kamiennego i brunatnego w Polsce i w Unii Europejskiej. Przegląd Górniczy 2010, 66, 1-8.

2. Lorek, E. Rozwój zrównoważony energetyki w wymiarze międzynarodowym, europejskim i krajowym; [w:] Graczyk, A. (red.): Teoria i praktyka zrównoważonego rozwoju, Akademia Ekonomiczna we Wrocławiu, Katedra Ekonomii Ekologicznej; Wydawnictwo EkoPress: Białystok-Wrocław, Poland, 2007; pp. 163-176.

3. Białecka, B.; Biały, W. Tereny Pogórnicze—Szanse, Zagrożenia. Analiza Przypadku; Monografia; Wydawnictwo PA NOVA: Gliwice, Poland, 2014.

4. Mishra, S.K.; Hitzhusen, J.F.; Sohngen, B.L.; Guldmann, J.M. Cost of abandoned coal mine reclamation and associated recreation benefits in Ohio. J. Environ. Manag. 2012, 100, 52-58. [CrossRef] [PubMed]

5. Gawlik, L. Kompozycja przyszłości energetycznej do 2050 roku według Światowej Rady Energetycznej; [w:] Światowe prognozy dla rynku energii. Izba Gospodarcza Gazownictwa; Warszawa, IV Kongres Polskiego Przemysłu Gazowniczego: Warszawa, Poland, 2014; pp. 58-66.

6. Gawlik, L.; Mokrzycki, E. Scenariusze wykorzystania węgla w polskiej energetyce w świetle polityki klimatycznej Unii Europejskiej. Przegląd Górniczy 2014, 70, 1-8.

7. Lorenz, U. Gospodarka Węlem Kamiennym Energetycznym; Wydawnictwo IGSMiE PAN: Kraków, Poland, 2011.

8. Lorenz, U.; Grudziński, Z. Międzynarodowe rynki węgla kamiennego energetycznego; Studia, Rozprawy, Monografie, Wydawnictwo Instytutu Gospodarki Surowcami Mineralnymi i Energią PAN: Kraków, Poland, 2009.

9. Sojda, A. Analiza statystyczna wskaźników finansowych dla przedsiębiorstw górniczych. Zeszyty Naukowe Politechniki Śląskiej, seria: Organizacja i Zarzadzanie 2014, 68, 255-264.

10. Michalak, A.; Nawrocki, T. Analiza porównawcza kosztu kapitału własnego przedsiębiorstw górnictwa węgla kamiennego w ujęciu międzynarodowym. Gospodarka Surowcami Mineralnymi = Mineral Resources Management 2015, 31, 49-72. [CrossRef]

11. Nawrocki, T.; Jonek-Kowalska, I. Assessing operational risk in coal mining enterprises-Internal, industrial and international perspectives. Resour. Policy 2016, 48, 50-67. [CrossRef]

12. Karbownik, A. Zarzadzanie procesem dostosowawczym w górnictwie węgla kamiennego w świetle dotychczasowych doświadczeń; Wydawnictwo Politechniki Śląskiej: Gliwice, Poland, 2005.

13. Dubiński, J.; Turek, M. Chances and threats of hard coal mining development in Poland-The results of experts research. Arch. Min. Sci. 2014, 59, 359-411.

14. Olkuski, T. Zasoby węgla kamiennego-najpewniejsze źródło energii. Przegląd Górniczy 2011, 7-8, 42-45.

15. Bak, P.; Michalak, A. Extraction Costs Forecast in the Hard Coal Mining Sector; [w:] Zbìrnik naukovih prac' Donec'kogo deržavnogo unìversitetu upravlìnnâ. Serìa: Tehničnì nauki: Upravlìnnâ proektami ta programami. T. 13, vip. 245; Donec'kij deržavnij universitet upravlinnâ: Donec'k, Ukraine, 2012; pp. 196-211.

16. Brzychczy, E. The planning optimization system for underground hard coal mines. Arch. Min. Sci. 2011, 56, 161-178.

17. Snopkowski, R. Próba oceny wpływu niestabilności efektywnego czasu pracy w ścianie na uzyskiwane wydobycie na podstawie badań modelowych. Przeglad Górniczy 2009, 65, 111-114.

18. Snopkowski, R.; Napieraj, A. Method of the production cycle duration time modeling within hard coal longwall faces. Arch. Min. Sci. 2012, 57, 121-138.

19. Jonek-Kowalska, I.; (red.). Zarządzanie kosztami w przedsiębiorstwach górniczych w Polsce. Stan aktualny i kierunki doskonalenia; Difin: Warszawa, Poland, 2013.

20. Turek, M. Analiza i ocena kosztów w górnictwie węgla kamiennego w Polsce w aspekcie poprawy efektywności wydobycia; Difin: Warszawa, Poland, 2013.

21. Bijańska, J.; Wodarski, K. Risk management in the planning of development projects in the industrial enterprises. Metalurgija 2014, 53, 276-278.

22. Zieliński, M. Efektywność-ujęcie ekonomiczne i społeczne. Zeszyty Naukowe Politechniki Ślaskiej, seria: Organizacja i Zarzadzanie 2013, 66, 137-148.

23. Mela, M.; Heinisuo, M. Weight and cost optimization of welded high strength steel beams. Eng. Struct. 2014, 79, 254-264. [CrossRef]

24. Pehrsson, L.; Ng, A.C.C.; Stockton, D. Industrial cost modelling and multi-objective optimization for decision support in production systems development. Comput. Ind. Eng. 2013, 66, 1036-1048. [CrossRef] 
25. Ouyang, L.Y.; Chen, C.K.; Chang, H.C. Quality improvement, set up cost and lead time reductions in lot size reorder point models with an imperfect production process. Comput. Oper. Res. 2001, 29, 1701-1717. [CrossRef]

26. Sarkar, B.; Chaudhuri, K.; Moon, I. Manufacturing setup cost reduction and quality improvement for the distribution free continuous-review inventory model with a service level constraint. J. Manuf. Syst. 2015, 34, 203-214. [CrossRef]

27. Yoo, S.H.; Kim, D.S.; Park, M.S. Lot sizing and quality investment with quality cost analyses for imperfect production and inspection processes with commercial return. Int. J. Prod. Econ. 2012, 140, 922-933. [CrossRef]

28. Camp, C.H.V.; Huq, F. $\mathrm{CO}_{2}$ and cost optimization of reinforced concrete frames using a big bang-big crunch algorithm. Eng. Struct. 2013, 48, 363-372. [CrossRef]

29. Cohen, R.R.H. Use of microbes for cost reduction of metal removal from metals and mining industry waste streams. J. Clean. Prod. 2006, 14, 1146-1157. [CrossRef]

30. Rahman, S.M.; Kirkman, G.A. Costs of certified emission reductions under the Clean Development Mechanism of the Kyoto Protocol. Energy Econ. 2015, 47, 129-134. [CrossRef]

31. Xiao, H.; Wei, Q.; Wang, H. Marginal abatement cost and carbon reduction potential outlook of key energy efficiency technologies in China's building sector to 2030. Energy Policy 2014, 69, 92-105. [CrossRef]

32. Giustolisi, O.; Berardi, L.; Laucelli, D. Supporting decision on energy vs. asset cost optimization in drinking water distribution networks. Procedia Eng. 2014, 70, 734-743. [CrossRef]

33. Mollahassani-Pour, M.; Abdollahi, A.; Rashidinejad, M. Application of a novel cost reduction index to preventive maintenance scheduling. Electr. Power Energy Syst. 2014, 56, 235-240. [CrossRef]

34. García-Barberena, J.; Monreal, A.; Mutuberria, A.; Sánchez, M. Towards cost-competitive solar towers-Energy cost reductions based on Decoupled Solar Combined Cycles (DSCC). Energy Procedia 2014, 49, 1350-1369. [CrossRef]

35. Sierpińska, M. Nowoczesne narzędzia zarządzania finansami w przedsiębiorstwie górniczym. Controlling projektów-jego zakres i narzędzia. Wiadomości Górnicze 2006, nr 5, 283-288.

36. Wodarski, K.; Bijańska, J. Prognozowanie rentowności produkcji węgla kamiennego na przykładzie wybranej kopalni; [w:] XVI Szkoła Ekonomiki i Zarządzania w Górnictwie 2011, Stowarzyszenie Inżynierów i Techników Górnictwa; Zarząd Główny: Katowice, Poland, 2011; pp. 173-176.

37. Turek, M.; Czabanka, J. Minimalizacja kosztów produkcji w Gliwickiej Spółce Węglowej SA. Przegląd Górniczy 1995, 2, 15-18.

38. Turek, M. Nosal, P. Kierunki działania w zakresie minimalizacji kosztów produkcji w Gliwickiej Spótce Wẹglowej, S.A.; Szkoła Ekonomiki i Zarządzania w Górnictwie, Akademia Górniczo- Hutnicza: Kraków, Poland, 1995; pp. 430-452.

39. Karbownik, A.; Turek, M. Zmiany w górnictwie wegla kamiennego-geneza, przebieg, efekty. Przegląd Górniczy 2011, 7-8, 11-18.

40. Lisowski, A. Podstawy ekonomicznej efektywności podziemnej eksploatacji złóż; Wydawnictwo GiG, Wydawnictwo PWN: Katowice-Warszawa, Poland, 2001.

41. Magda, R. Możliwości obniżania cen zbytu węgla w zależności od przyjętego poziomu średniej akumulacji jednostkowej ze sprzedaży. Wiadomości Górnicze 2014, 1, 47-52.

42. Gorczyńska, A. Zarzadzanie kosztami w przedsiębiorstwie w świetle badań literaturowych; [w:] Jonek-Kowalska, I. (red.): Zarządzanie kosztami w przedsiębiorstwach górniczych w Polsce. Stan aktualny I kierunki doskonalenia; Difin: Warszawa, Poland, 2013; pp. 13-21.

43. Turek, M. System zarzadzania kosztami w cyklu istnienia wyrobiska wybierkowego w kopalni węgla kamiennego; Difin: Warszaw, Poland, 2013.

44. Tee, K.F.; Khan, L.R.; Chen, H.P.; Alani, A.M. Reliability based life cycle cost optimization for underground pipeline networks. Tunn. Undergr. Space Technol. 2014, 43, 32-40. [CrossRef]

45. Trojnar, A.; Więckol-Ryk, A.; Niemiec, B. Koszty profilaktyki zagrożenia tąpaniami w kopalniach węgla kamiennego. Wiadomości Górnicze 2014, 4, 209-221.

46. Czopek, K. Sposób wyznaczania i wykorzystania kosztów stałych w kopalniach węgla brunatnego; Prace Naukowe Instytutu Górnictwa Politechniki Wrocławskiej, nr 98, Seria Konferencje: Nr 34; Materiały III Międzynarodowego Kongresu Górnictwa Węgla Brunatnego: Bełchatów, Poland, 2002; pp. 111-118. 
47. Gawlik, L. Koszty stałe i zmienne pozyskania węgla kamiennego jako element zarządzania produkcja. Polityka Energetyczna 2007, 10, 471-482.

48. Dźwigoł, H. Oddziałowy Rachunek Kosztów oraz model budżetowania kosztów w górnictwie węgla kamiennego; Materiały konferencyjne z konferencji naukowej nt. Reformy polskiego górnictwa węla kamiennego; Zarządzanie innowacjami: Szczyrk, Poland, 2001. 